\title{
Farmers' Demand for Informal Risk Management Strategy and Weather Index Insurance: Evidence from China
}

\author{
Yingmei Tang ${ }^{1} \cdot$ Huifang Cai ${ }^{1} \cdot$ Rongmao Liu $^{1}$
}

Accepted: 23 January 2021/Published online: 7 April 2021

(C) The Author(s) 2021

\begin{abstract}
In the absence of formal risk management strategies, agricultural production in China is highly vulnerable to climate change. In this study, field experiments were conducted with 344 households in Heilongjiang (Northeast China) and Jiangsu (East China) Provinces. Probit and logistic models and independent sample $T$-test were used to explore farmers' demand for weather index insurance, in contrast to informal risk management strategies, and the main factors that affect demand. The results show that the farmers prefer weather index insurance to informal risk management strategies, and farmers' characteristics have significant impacts on their adoption of risk management strategies. The variables non-agricultural labor ratio, farmers' risk perception, education, and agricultural insurance purchase experience significantly affect farmers' weather index insurance demand. The regression results show that the farmers' weather index insurance demand and the influencing factors in the two provinces are different. Farmers in Heilongjiang Province have a higher participation rate than those in Jiangsu Province. The government should conduct more weather index insurance pilot programs to help farmers understand the mechanism, and insurance companies should provide more types of weather index insurance to meet farmers' diversified needs.
\end{abstract}

Keywords China - Informal risk management strategies - Natural hazards and disasters - Weather index insurance

Rongmao Liu

liurm@njau.edu.cn

1 College of Finance, Nanjing Agricultural University, Nanjing 210095, China

\section{Introduction}

Climate change is making weather more unpredictable and extreme weather events, including floods and droughts, more frequent (National Bureau of Statistics 2020). In 2016, natural hazards and disasters affected 22.65 million ha of crops in China, of which 2.9 million ha had no harvests, and the direct economic loss was $\mathrm{RMB}^{1} 503.29$ billion yuan. ${ }^{2}$ Rural households are highly exposed to natural risks. When farmers are adversely affected by weather shocks, sound climate risk management strategies can improve livelihoods, contribute to poverty alleviation, and enable farmers to take production risks (Brouwer et al. 2013; Norton et al. 2014). The combination of climate and socioeconomic changes will increase the demand for insurance coverage to limit the impacts of climate change (Clement et al. 2018).

Farmers' risk management strategies can be categorized into informal and formal types. A lack of access to affordable financial services forces the poor in developing countries to employ risk avoidance, risk diversification, and informal risk-sharing practices. Informal risk management strategies include household savings, borrowing from friends and relatives, mutual support networks of neighbors, diversified cultivation, and non-farming activities (Skees and Barnett 2006; Skees 2008; Akter et al. 2009; Mozumder et al. 2009). In China, farmers mainly use savings and social networks to manage natural risks. These strategies are effective at managing idiosyncratic risks that affect only some families and cause household-specific adverse shocks (Mosley 2001; Skees 2003; Hoogeveen

\footnotetext{
$\overline{1}$ RMB 1 yuan $=$ USD 0.1441 (at the time the economic loss numbers were posted).

${ }^{2}$ China National Bureau of Statistics: http://www.stats.gov.cn/.
} 
et al. 2004; Clement et al. 2018). However, savings and other informal risk management strategies may be insufficient in dealing with covariate risks caused by adverse weather, risks that influence the income of all rural households in the same area (Miranda and Vedenov 2001; Linnerooth et al. 2005; Sawada 2007; Trærup 2012; Sarris 2013; Bogale 2015; Farrin and Miranda 2015).

One of the promising means to ensure the stability of rural society when faced with natural hazards and disasters is to establish an agricultural insurance system (Skees et al. 2002; Wang et al. 2011). Since 2004, policy-based, multiperil crop insurance (MPCI) has developed rapidly with government fiscal support in China (Wang et al. 2011; Xiao and Yao 2019). But the MPCI's sustainability is plagued by high administrative costs, moral hazard, and adverse selection (Berhane et al. 2013; Zhao et al. 2016; Ye et al. 2017). Index-based insurance indemnifies policyholders based on the observed value of an "index" that is highly correlated with losses. Weather index insurance (WII) can avoid some drawbacks of traditional insurance and is more affordable and easier to administer. It is offered as an alternative to traditional claim-based insurance in developing countries (Barnett et al. 2008; Collier et al. 2009; Hellmuth et al. 2009; Wang et al. 2011; Miranda and Farrin 2012; Sarris 2013; Norton et al. 2014; Ye et al. 2017; Clement et al. 2018).

Basis risk is an inherent defect of index insurance, and occurs when there is a gap between the insurance indemnity and farmers' actual losses (Akter et al. 2009; Cole et al. 2013; Jensen et al. 2016; Marr et al. 2016; Clement et al. 2018). Basis risk increases farmers' costs and makes taking up WII a costly gamble rather than a useful risk management tool, and is often known as the major obstacle to the increasing uptake rate of WII (Akter et al. 2009; Hazell and Hess 2010; Clarke 2011; Miranda and Farrin 2012; Castellani et al. 2014; Jensen et al. 2016). The effective demand for WII is often limited by the impact of the basis risk, and considerably lowers the demand for WII products because the contracts fail to provide protections against agricultural risks, especially for low-income farmers (Sarris 2013; Clarke and Dercon 2016; Clement et al. 2018; Liu et al. 2019; Xiao and Yao 2019). Therefore, it is unclear whether farmers prefer to adopt WII or informal risk management methods.

The decision on purchasing crop insurance is affected by many factors (Fahad et al. 2018). In China, smallholder farmers' knowledge of and experience with agricultural insurance is very limited (Patt et al. 2009; Ye et al. 2016). Trust in and familiarity with the local insurance provider has been shown to be an important determinant of insurance demand (Cole et al. 2014; Karlan et al. 2014; Wang et al. 2016; Cai and Song 2017). Personal experience with disaster, perceptions of disaster risk management tools, government subsidies, and the knowledge of the payout probability are also main drivers of insurance demand (Zhang et al. 2015; Ye et al. 2016; Cai and Song 2017; Liu et al. 2019; Ye et al. 2020).

Some researchers have found that the uptake rate of WII is quite low as a result of high price elasticity, farmers' liquidity constraints, and lack of trust in the government or the insurance company (Binswanger-Mkhize et al. 2012; Cole et al. 2013; Hill et al. 2013; Cai and Song 2017). Low-income farmers are not willing to take on the uncertainty associated with WII-they prefer self-insurance, such as reducing consumption or selling their valuables, to smooth risk (Clarke and Dercon 2009; Giné and Yang 2009; Kong and Yuan 2010; Turvey and Kong 2010; Norton et al. 2014; Farrin and Miranda 2015). Household savings are often used as a popular informal risk-sharing strategy to smooth consumption when facing uninsured risk in some developing countries where insurance is costly (Norton et al. 2014; Farrin and Miranda 2015). Thus, weather index insurance products should not be examined in isolation from other risk management tools (Clement et al. 2018).

The literature on the demand for WII in developing countries is quite extensive, but research on WII demand and research that considers the impact of informal risk management strategies with respect to China is rare. Chinese households have strong saving motives, which may significantly influence their demand for WII (Zhou 2010; Nie and Shen 2016). Clarke et al. (2015) and Dercon et al. (2014) conducted field experiments in Bangladesh and Ethiopia, where index insurance is offered alongside other risk management options, to examine farmers' demand. Because of different climatic, economic, political, and institutional conditions, farmers' participation in agricultural insurance may vary with countries and regions (Hisali et al. 2011). Further study with Chinese samples is needed.

This study investigated Chinese farmers' trading off between formal insurance products (weather index insurance) and an informal risk management method (saving), to contribute to the growing literature by demonstrating Chinese farmers' demand for WII compared with saving. Which of these two methods is preferred by farmers? What are the factors influencing farmers' choices? We explored these questions by using survey data from field experiments with households in Northeast China (Heilongjiang Province) and East China (Jiangsu Province). The game design followed the studies by Clarke et al. (2015), Norton et al. (2014), and Cai and Song (2017). Section 2 outlines the data and methods. Section 3 presents the empirical analysis and Sect. 4 a brief discussion. 


\section{Methods and Data Collection}

This section introduces the study areas, sampling, experiment scenario, and experiment process.

\subsection{Study Areas}

We collected data through field experiments conducted in July and October 2017 in Hulan District ${ }^{3}$ and Mulan and Tonghe Counties in Heilongjiang Province, and Jurong City $^{4}$ and Guanyun County in Jiangsu Province (see Table 1 and Fig. 1).

The study areas in Heilongjiang Province are within the main rice growing area, located along the banks of the Songhua River in Northeast China. They are in one of the major food-producing regions in China that harvests annual crops, and rice production is dominant in this area (Lu et al. 2017). In Heilongjiang Province, the per capita arable land is $6.27 \mathrm{mu}$ (about $0.42 \mathrm{ha}$ ). ${ }^{5}$ Rainfall in the province averages $721.49 \mathrm{~mm}$ annually, ${ }^{6}$ and its distribution is uneven throughout the year. Some cultivated lands are located in hills and are vulnerable to drought disasters; but the main parts of the cultivated land are located on the plains, which are vulnerable to floods due to their close proximity to the Songhua River. In 2013, the study area suffered a major flood disaster and most households in this region already took up MPCI to manage agricultural risks, and are expected to have a deeper understanding of natural risks and agricultural insurance.

Jiangsu Province is an important area in the reform and innovation of agricultural insurance in East China, and is more densely populated with lower per capita arable land ( $0.85 \mathrm{mu} /$ about $0.06 \mathrm{ha}$ ) than Heilongjiang Province. The terrain of Guanyun County is mainly plain, and it is a national commodity grain production base county, mainly producing grain, cotton, vegetables, and other crops. The topography of Jurong City is high and flat, in which low mountain area accounts for $16 \%$, hilly land accounts for $71 \%$, and it mainly produces wheat, rice, and other crops. The two study areas in Jiangsu Province have abundant rainfall, at an annual average of $825.5 \mathrm{~mm}$ in the province, ${ }^{7}$ mild climate all year around, and good irrigation conditions and facilities.

\footnotetext{
3 A district of Harbin City.

${ }^{4}$ A county-level city under Zhenjiang City in Jiangsu Province.

${ }^{5}$ Per capita arable land was calculated based on the data from China Statistical Yearbook 2018 (http://www.stats.gov.cn/tjsj/ndsj/2018/ indexch.htm). It equals the total cultivated land area of the province divided by the total population. $1 \mathrm{mu}=666.67 \mathrm{~m}^{2}=0.06667 \mathrm{ha}$.

${ }^{6}$ Heilongjiang Province Statistical Yearbook 2020 (http://tjj.hlj.gov. cn/app/tongjnj/2020/zk/indexch.htm).

7 Jiangsu Province Statistical Yearbook 2019 (http://tj.jiangsu.gov. cn/2020/nj09.htm).
}

Due to the differences of climate, terrain, and geographic proximity to river, farmers in the study areas of Heilongjiang Province face higher flood risks than those in the study areas of Jiangsu Province. Farmers in Jiangsu Province are more likely to face high temperature risks. These differences in geographic location, modes of agricultural production, and frequency of natural hazards and disasters may lead to farmers' different demand for WII. Thus, we chose these two provinces as study areas.

\subsection{Sampling}

To ensure that the subjects understood the research experiment context, participants were required to have more than five years of planting experience, be responsible for their households' decision making, and have received primary education (5 or 6 years). We obtained resident lists from local officials and chose farmers who met these criteria, then randomly recruited subjects using the list. There are about 200 households in each village and approximately 10 households per village were recruited as subjects. A total of 344 sample households were randomly recruited from 32 villages, and 1,032 sets of observations were obtained from three rounds of testing weather index insurance demand (see Sect. 2.4.2 on Weather Index Insurance Demand) with each of the 344 households.

\subsection{Experiment Scenario}

To simplify the research experiment, each farmer was provided with $10 \mathrm{mu}$ (about $0.7 \mathrm{ha}$ ) of land and RMB 500 yuan (about USD 75) (after deducting production costs) as an initial endowment to simulate agricultural production. To ensure the experimental parameters were close to reality, the planting costs and income were obtained through focus interviews in the preliminary research, and were RMB 600 yuan (about USD 90) and RMB 1,100 yuan (about USD 165) per $m u$, respectively. According to local climatic conditions, a hypothetical rice temperature and rainfall composite index insurance was designed. The weather index insurance premium was RMB 25 yuan (about USD 3.75) per $m u$ after deducting government subsidies, and the maximum indemnity was RMB 220 yuan (about USD 33) per $т и$. The insurance terms followed the contract of Guoyuan Insurance Company, the first company to conduct a WII pilot project in China in 2009 . Borrowing money from relatives and friends is prevalent in the study areas because the ceiling of bank loans cannot meet the funding needs of farmers and the procedures of take-out loans are complicated. The annual interest rates of local rural financial institutions range from 8 to $15 \%$, and the interest rate was set at $10 \%$ in the experiment. 
Table 1 Sample distribution in the study areas of Heilongjiang and Jiangsu Provinces, China

\begin{tabular}{|c|c|c|c|c|}
\hline Province & County & Number of sample towns & Number of sample villages & Number of sample households \\
\hline \multirow[t]{3}{*}{ Heilongjiang } & Mulan & 4 & 8 & 89 \\
\hline & Hulan & 3 & 6 & 72 \\
\hline & Tonghe & 2 & 4 & 48 \\
\hline Subtotal & & 9 & 18 & 209 \\
\hline \multirow[t]{2}{*}{ Jiangsu } & Guanyun & 4 & 8 & 82 \\
\hline & Jurong & 3 & 6 & 53 \\
\hline Subtotal & & 7 & 14 & 135 \\
\hline Total & & 16 & 32 & 344 \\
\hline
\end{tabular}

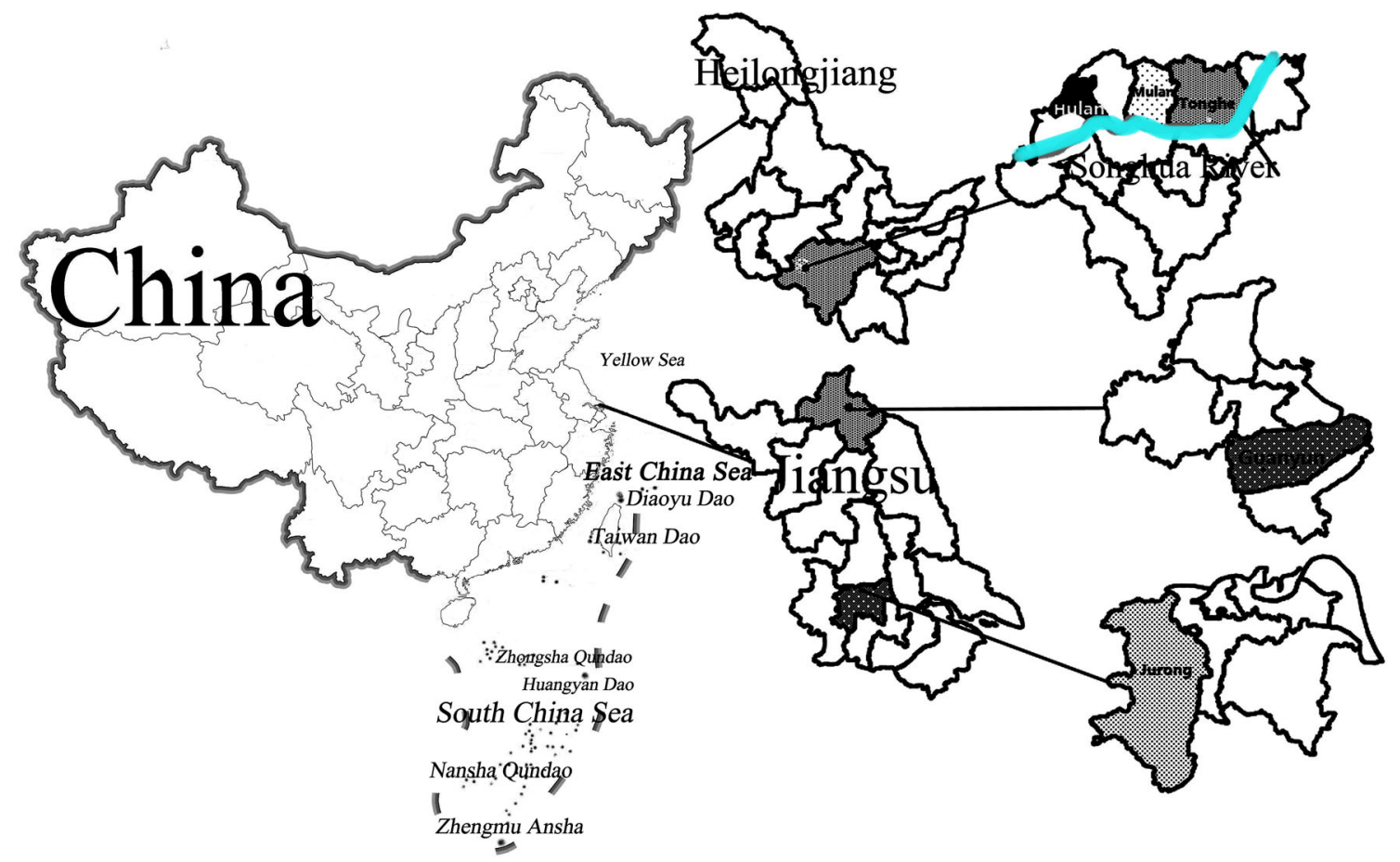

Fig. 1 Location of the study areas in China

The weather conditions were simplified as normal weather $(70 \%)$ and bad weather $(30 \%),{ }^{8}$ based on local historical meteorological data. Some parts of the study areas are located in the plains, and others are in the hills. Thus even with the same weather conditions, farmers' losses may be different. In the experiment, if farmers suffered bad weather, the proportions of farmers' losses to annual income were set as $40 \%, 60 \%$, and $80 \%$, respectively, and the probability was $1 / 3$ for each. The experiment parameters are shown in Table 2.

\footnotetext{
8 When the national standardized precision index is between -1.0 and 1.48 , it is normal weather, otherwise it is bad weather.
}

\subsection{Experiment Process}

The research experiment consisted of four parts: (1) a game introducing the concept of weather index insurance; (2) a test of weather index insurance demand; (3) a game testing farmers' risk preference; and (4) a short questionnaire survey.

\subsubsection{A Game Introducing Weather Index Insurance}

Because WII is not available in the study area, a full understanding of this product and its basis risk was crucial for the experiment design. Thus a game was played to help farmers understand this product. 
Table 2 The experiment parameters for the study areas in Heilongiiang and Jiangsu Provinces, China. Source: Authors' calculation based on data collected during the 2017 field experiments

\begin{tabular}{|c|c|c|c|c|c|c|}
\hline \multicolumn{3}{|c|}{ Agricultural production conditions } & \multicolumn{4}{|c|}{ Risk management strategy } \\
\hline Weather & Planting cost (yuan) & $\begin{array}{l}\text { Planting } \\
\text { income (yuan) }\end{array}$ & $\begin{array}{l}\text { Saving } \\
\text { Interest rate }(\%)\end{array}$ & $\begin{array}{l}\text { Saving } \\
\text { Interest (yuan) }\end{array}$ & $\begin{array}{l}\text { Insurance } \\
\text { premium (yuan) }\end{array}$ & $\begin{array}{l}\text { Insurance } \\
\text { indemnity (yuan) }\end{array}$ \\
\hline Normal & 6000 & 11,000 & 10 & 50 & 250 & 0 \\
\hline $\mathrm{Bad}$ & 6000 & 2200 & 10 & 50 & 250 & 2200 \\
\hline $\mathrm{Bad}$ & 6000 & 4400 & 10 & 50 & 250 & 2200 \\
\hline $\mathrm{Bad}$ & 6000 & 6600 & 10 & 50 & 250 & 2200 \\
\hline
\end{tabular}

First, the concept of weather index insurance was explained as follows: WII indemnifies based on an actual weather index measured by the nearest weather station. If there is a difference between the actual rainfall/temperature and the contract index (the trigger point), the insured farmers will all be indemnified automatically with the same amount, no matter how much their losses are. Second, farmers simulated production, and one of the farmers drew lots to determine the rainfall/temperature. If the rainfall/ temperature reached the trigger point, all farmers would obtain equal indemnity. Subsequently, each farmer drew lots to determine their individual losses. The difference between the indemnity and the individual losses was the basis risk. Finally, a quiz of WII was administered. If the farmers failed to give correct answers, the research team would explain the key points again until the participants fully understood how WII worked.

\subsubsection{A test of Weather Index Insurance Demand}

First, the tasks and scenarios of this part of the four-part experiment were introduced to the farmers. Then the farmers decided how to allocate the initial endowmentdepositing the money to earn interest or purchasing WII. Subsequently, the farmers drew lots to determine the weather conditions and individual losses (if they suffered bad weather). Finally, the research team calculated the farmers' incomes, which were carried over to the next round as start-up funds. To determine the farmers' choice between saving the money and purchasing WII under different climate and gain scenarios, this part of the four-part experiment was conducted for three rounds, representing three planting cycles. To avoid farmers being affected by their peers, they were separated to ensure that they could not see other farmers' choices and talk with each other throughout this part of the experiment.

\subsubsection{A Game Testing Farmers' Risk Preference}

Giné et al. (2008), Ye and Wang (2013), and Jin et al. (2016) found that risk preferences affect farmers' insurance purchase and willingness to pay. A game was designed to test farmers' risk preferences based on the research by Cole et al. (2014) and Brick and Visser (2015).

The subjects were asked to choose from two options (see Table 3). Option one was to get money directly and the amount varied from RMB 3-25 yuan (about USD 3.75). Option two was to draw balls to determine the amount a farmer can get. There were seven black balls (representing RMB 0 yuan) and three white balls (representing RMB 50 yuan) in the bag. If a farmer chose option two, the amount of option one would increase by RMB 2 yuan per turn, and the game would not end until the farmer chose option one. The number of times of choosing option two is the farmer's risk preference score, which ranges from 0 to 12 . The higher the score, the more tolerance for risk the farmer has.

\subsubsection{A Short Questionnaire Survey}

A questionnaire survey was conducted to collect farmers' individual and family socioeconomic data. The questionnaire also included farmers' experiences of agricultural insurance and natural hazards and disasters, risk perception, the proportion of loss to farming income, and nonagricultural labor ratio. This part of the four-part research experiment lasted for 60 minutes, and each farmer was paid RMB 70 yuan (about USD 10), which is close to two hours' wage of local labor.

\section{Empirical Analysis}

In this section, farmers' choices between saving and WII were analyzed. Then the impact of risk preference on farmers' demand and the characteristics of farmers were discussed. Probit and Logistic models were both employed to further investigate the effect of farmers' characteristics on WII demand. 
Table 3 Risk preference testing game conducted with farmers in the study areas of Heilongjiang and Jiangsu Provinces, China

\begin{tabular}{llll}
\hline Option one (get money directly) & & \multicolumn{2}{l}{ Option two (draw a ball) } \\
Order & Amount (yuan) & Black ball (yuan) & White ball (yuan) \\
\hline 1 & 3 & 0 & 50 \\
2 & 5 & 0 & 50 \\
3 & 7 & 0 & 50 \\
4 & 9 & 0 & 50 \\
5 & 11 & 0 & 50 \\
6 & 13 & 0 & 50 \\
7 & 15 & 0 & 50 \\
8 & 17 & 0 & 50 \\
9 & 19 & 0 & 50 \\
10 & 21 & 0 & 50 \\
11 & 23 & 0 & 50 \\
\hline
\end{tabular}

\subsection{Comparative Analysis between Demand for Saving and Weather Index Insurance}

In the three rounds of part 2 of the research experiment (see Sect. 2.4.2 on Weather Index Insurance Demand), only an average of $19.67 \%$ of farmers chose saving as a risk management method (Table 4). The farmers who chose insurance accounted for over $80 \%$ of the total samples. This indicates that the farmers are more likely to choose WII, compared with informal risk management methods. Farmers' demand for weather index insurance is stable even if the weather conditions changed randomly in the three rounds.

After two rounds, farmers had experienced different weather conditions and were more familiar with the basis risk of WII. The choice of the round before may have affected the choice of the next round, when we compared farmers' choices in the second and third rounds. Table 5 indicates that $97 \%$ of the farmers who chose WII in the second round still chose insurance in the third round. Among the farmers who chose saving in the second round,
$81 \%$ switched to WII in the next round; only $18.57 \%$ of the farmers continued to choose saving. Taken together, compared with informal risk manage methods, farmers were more willing to adopt a formal risk management strategy due to its higher efficiency at diversifying natural risks. But whether the result is statistically significant requires further testing.

Following the research by Norton et al. (2014), the binomial distribution was used to further analyze if the difference of farmers' demand for risk management tools is significant. In Table 6, the value of accuracy (bilateral) is significant at the $1 \%$ level in both the total samples and the subregional samples, which means that the difference of farmers' demand for two risk management tools is significant. It indicates that if weather index insurance is available, farmers are more willing to choose the insurance rather than saving the money to deal with natural risks. The reason may be that savings cannot effectively diversify the risks caused by extreme weather (Feng and Yang 2011; Colson et al. 2014; Farrin and Miranda 2015). Farmers' participation rate in weather index insurance was $88 \%$ and

Table 4 Farmers' choices of different risk management methods in the study areas of Heilongjiang and Jiangsu Provinces, China $(\mathrm{n}=344)$. Source: Authors' calculations, based on data collected during the 2017 field experiments

\begin{tabular}{lllll}
\hline Rounds & \multicolumn{2}{l}{ Saving the money } & & \multicolumn{2}{l}{ Purchasing weather index insurance } \\
\cline { 2 - 3 } \cline { 5 - 6 } & Number & Rate $(\%)$ & Number & Rate $(\%)$ \\
\hline Round 1 & 70 & 20 & 274 & 80 \\
Round 2 & 70 & 20 & 274 & 80 \\
Round 3 & 65 & 19 & 279 & 81 \\
Average of three rounds & 68 & 19.67 & 276 & 80.33 \\
\hline
\end{tabular}


Table 5 Effect of a farmer's choice on the next round's choice in the testing of weather index insurance (WII) demand in the study areas of Heilongjiang and Jiangsu Provinces, China

\begin{tabular}{llc}
\hline Farmer's choices & Selected WII in round 2 $(\%)$ & Selected savings in round 2 $(\%)$ \\
\hline Selected WII in round 3 & 97.08 & 81.43 \\
Selected savings in round 3 & 2.92 & 18.57 \\
\hline
\end{tabular}

Table 6 Binary distribution test in the context of weather index insurance demand in the study areas of Heilongjiang and Jiangsu Provinces, China

\begin{tabular}{llllll}
\hline Province & $\mathrm{N}$ & Inspection ratio $^{\mathrm{a}}$ & Observations of index insurance demand & Observation ratio & Accuracy (bilateral) \\
\hline Heilongjiang & 627 & 0.50 & 552 & 0.88 & $0.000^{* * *}$ \\
Jiangsu & 405 & 0.50 & 275 & 0.68 & $0.000^{* * *}$ \\
Total & 1032 & 0.50 & 827 & 0.80 & $0.000^{* * *}$
\end{tabular}

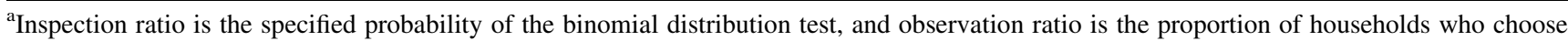
weather index insurance to the total samples

$68 \%$ in Heilongjiang and Jiangsu, respectively. Farmers in Heilongjiang Province were more likely to purchase weather index insurance than farmers in Jiangsu Province.

\subsection{Impact of Risk Preference on Farmers' Demand for Saving and Weather Index Insurance}

Binswanger (1980) divided all farmers into three groupsrisk averse, risk neutral, and risk seeking. In this experiment, the farmers were also divided into three categories according to their risk scores $(0-12)$. The risk scores of 0-4 and 5-8 indicate risk averse and risk neutral, respectively. Farmers with a risk score of 9-12 are risk seeking. Table 7 shows that among all household samples, $18.32 \%$ of the farmers are risk neutral. Risk-averse and risk-seeking farmers account for $43.31 \%$ and $38.37 \%$, respectively-the average risk preference of all farmers is to be risk neutral.

Among the risk-neutral and risk-seeking farmers, the proportion of demand for WII is as high as $85.71 \%$ and $82.58 \%$, respectively. Risk-averse farmers have the lowest demand $(74.5 \%)$. This indicates that regardless of the farmer's risk preference, the farmers prefer WII to saving, and risk-averse farmers are more willing to choose informal risk management strategies. Clarke (2011) found that if farmers paid the insurance premium without getting compensation when disasters happened, they would be less willing to buy insurance and turn to lower-cost informal risk management strategies. Ye and Wang (2013) and Tong et al. (2019) suggested that more risk-averse farmers tend to diversify their income structure (that is, engage in offfarm activities) and reduce the proportion of their income from farming, which effectively mitigates income risk.

\subsection{What are the Characteristics of Farmers in Different Risk Management Strategies?}

Previous studies have found that the socioeconomic characteristics of farmers and some other factors influence the agricultural insurance demand. Farm size and education level of farmers are correlated with the decision to purchase insurance (Wang et al. 2016). Agricultural insurance affordability is the primary factor in farmers' agricultural

Table 7 Farmers' risk preference and demand for risk management strategy in the study areas of Heilongiiang and Jiangsu Provinces, China $(n=344)$. Source: Authors' calculations, based on data collected during the 2017 field experiments

\begin{tabular}{|c|c|c|c|c|c|c|}
\hline \multirow[t]{2}{*}{ Demand for risk management strategy } & \multicolumn{2}{|c|}{ Risk averse $(0-4)$} & \multicolumn{2}{|c|}{ Risk neutral (5-8) } & \multicolumn{2}{|c|}{ Risk seeking $(9-12)$} \\
\hline & Number & Rate $(\%)$ & Number & Rate $(\%)$ & Number & Rate $(\%)$ \\
\hline Distribution of preferences & 149 & 43.31 & 63 & 18.32 & 132 & 38.37 \\
\hline Weather index insurance & 111 & 74.50 & 54 & 85.71 & 109 & 82.58 \\
\hline Saving & 38 & 25.50 & 9 & 14.29 & 23 & 17.42 \\
\hline
\end{tabular}


Table 8 Definition and descriptive statistics of variables and independent sample $T$-test of farmers' characteristics in the study areas of Heilongjiang and Jiangsu Provinces, China

\begin{tabular}{|c|c|c|c|c|c|c|}
\hline \multirow[t]{2}{*}{ Variables } & \multirow[t]{2}{*}{ Definition } & \multirow[t]{2}{*}{ Mean } & \multirow[t]{2}{*}{ SD } & \multicolumn{3}{|c|}{ Independent sample $T$-test } \\
\hline & & & & Saving & WII & Difference \\
\hline Y1 & If farmers select WII in all three rounds $\mathrm{Y} 1=1$, otherwise it is 0. & 0.80 & 0.399 & 205 & 827 & \\
\hline Y2 & Farmers' choice in the first round. Select WII $=1$, select saving $=0$ & 0.80 & 0.403 & 70 & 274 & \\
\hline Y3 & $\begin{array}{l}\text { Farmers' choice in the second round. Select WII }=1 \text {, select } \\
\quad \text { saving }=0\end{array}$ & 0.80 & 0.403 & 70 & 274 & \\
\hline Y4 & $\begin{array}{l}\text { Farmers' choice in the third round. Select WII }=1 \text {, select } \\
\text { saving }=0\end{array}$ & 0.81 & 0.392 & 65 & 279 & \\
\hline Gender & Male $=1$, female $=0$ & 0.85 & 0.362 & $\begin{array}{l}0.86 \\
(0.042)^{\mathrm{a}}\end{array}$ & $\begin{array}{l}0.84 \\
\quad(0.022)\end{array}$ & -0.014 \\
\hline Age & Age & 51.42 & 10.060 & $\begin{array}{l}53.43 \\
\quad(1.262)\end{array}$ & $\begin{array}{l}50.91 \\
\quad(0.597)\end{array}$ & $-2.520^{*}$ \\
\hline Edu & Years of education & 7.29 & 2.819 & $7.30(0.343)$ & $7.29(0.170)$ & -0.008 \\
\hline Far & Years of farming & 28.12 & 12.500 & $\begin{array}{l}28.04 \\
\quad(1.547)\end{array}$ & $\begin{array}{l}28.14 \\
\quad(0.750)\end{array}$ & 0.099 \\
\hline Non & Non-agricultural labor ratio & 0.20 & 0.259 & $0.28(0.035)$ & $0.18(0.015)$ & $-0.102 * * *$ \\
\hline Scale & Land holding $(m u)$ & 79.04 & 120.50 & $\begin{array}{l}51.96 \\
\quad(8.837)\end{array}$ & $\begin{array}{l}85.96 \\
\quad(7.790)\end{array}$ & $34.006 * *$ \\
\hline Dis & $\begin{array}{l}\text { Farmers' experience of natural hazards and disasters (Yes }=1 \text {, } \\
\text { No }=0 \text { ) }\end{array}$ & 0.65 & 0.479 & $0.49(0.060)$ & $0.69(0.028)$ & $0.200 * * *$ \\
\hline Loss & Rate of disaster loss to farming income & 0.25 & 0.288 & $0.22(0.039)$ & $0.26(0.017)$ & 0.038 \\
\hline Exp & $\begin{array}{l}\text { Farmers' agricultural insurance purchase experience (Yes }=1 \text {, } \\
\text { No }=0 \text { ) }\end{array}$ & 0.72 & 0.449 & $0.53(0.060)$ & $0.77(0.025)$ & $0.242 * * *$ \\
\hline Risk & Risk perception ${ }^{\mathrm{b}}$ & 3.26 & 1.154 & $2.83(0.148)$ & $3.38(0.067)$ & $0.547 * * *$ \\
\hline Pre & Risk preference score $(0-12)$ & 6.03 & 4.690 & $4.97(0.578)$ & $6.31(0.279)$ & $1.335 * *$ \\
\hline
\end{tabular}

WII Weather index insurance

$*$, **, and *** are significant at the statistical levels of $10 \%, 5 \%$, and $1 \%$, respectively

${ }^{\mathrm{a}}$ The values in parentheses are standard errors

${ }^{\mathrm{b}}$ Farmers' prediction of the degree of future agricultural production risks (very low $=1$; not too high $=2$; normal $=3$; high $=4$; very high $=5$ )

insurance purchasing decision making (Liu et al. 2016). Net income, on-farm income, and total income are all variables that affect agricultural insurance consumption (Jin et al. 2016; Wang et al. 2016; Ye et al. 2016). In this study, the non-agricultural labor ratio was used as a proxy for off-farm income to explore the impact of income sources on insurance demand. Wang et al. (2012) found that insurance participation experience, particularly indemnity experience, can substantially increase the probability of participation. Cai and Song (2017) and Liu et al. (2019) found that experience with natural hazards and disasters may influence individual insurance purchase decisions. Liu et al. (2016), Han et al. (2017), and Xu et al. (2018) suggested that risk perception had important influences on disaster preparedness. Following these studies, the information on farmers' socioeconomic characteristics and disaster experiences was collected through the questionnaire survey.

Most subjects were male and their average age was 51 (Table 8). The subjects' average length of primary education was 7.29 years. This means that most of them dropped out in middle school. The subjects were experienced in farming (28 years of farming). The non-agricultural labor ratio was only $20 \%$ because industry and commerce are not well developed in the study areas. The average land holding was $79.04 \mathrm{mu}$ (about $5.3 \mathrm{ha}$ ) because Heilongjiang is sparsely populated and its sample households accounted for $60 \%$ of the total samples. Nearly $65 \%$ of farmers had experienced natural hazards and disasters, and the average rate of disaster loss to farming income was $25 \%$. Of the subject households $72 \%$ had purchased MPCI-this means that most farmers are familiar with agricultural insurance. The average risk perception was 3.26 , that is, most subjects thought the agricultural production risk was nearly normal. The average risk preference score was 6.03 , at the middle of the range between 0 and 12 . Generally speaking, the farmers are risk neutral. Their perception of future risks is normal.

The independent sample $T$-test was applied to examine the significance of the differences between the 
Table 9 Descriptive statistics of variables of farmers' characteristics in the study areas of Heilongjiang and Jiangsu Provinces, China and $T$-test results

\begin{tabular}{|c|c|c|c|c|c|c|c|c|}
\hline \multirow[t]{2}{*}{ Variables } & \multirow[t]{2}{*}{ Definition } & \multicolumn{3}{|c|}{ Heilongjiang Province } & \multicolumn{3}{|l|}{ Jiangsu Province } & \multirow[t]{2}{*}{$T$-test } \\
\hline & & Mean & Min & Max & Mean & Min & Max & \\
\hline Gender & Male $=1$, female $=0$ & $0.784(0.412)^{\mathrm{a}}$ & 0 & 1 & $0.941(0.237)$ & 0 & 1 & $4.012 * * *$ \\
\hline Age & Age & 49.606 (10.19) & 26 & 77 & $54.207(9.223)$ & 31 & 75 & $4.234 * * *$ \\
\hline Edu & Years of education & $6.899(2.515)$ & 0 & 16 & $7.933(3.137)$ & 0 & 16 & $3.377 * * *$ \\
\hline Far & Years of farming & $27.466(11.97)$ & 2 & 57 & $29.081(13.27)$ & 1 & 56 & 1.169 \\
\hline Non & Non-agricultural labor ratio & $0.136(0.226)$ & 0 & 1 & $0.308(0.272)$ & 0 & 0.8 & $6.373 * * *$ \\
\hline Scale & Land holding $(m u)$ & $101.442(119.8)$ & 10 & 1200 & $44.233(113.5)$ & 1 & 710 & $-4.404 * * *$ \\
\hline Dis & $\begin{array}{l}\text { Farmers' experience of natural hazards and disasters } \\
\quad(\text { Yes }=1, \text { No }=0)\end{array}$ & $0.817(0.391)$ & 0 & 1 & $0.385(0.488)$ & 0 & 1 & $-9.094 * * *$ \\
\hline Loss & Rate of disaster loss to farming income & $0.311(0.281)$ & 0 & 1 & $0.164(0.276)$ & 0 & 1 & $-4.776^{* * *}$ \\
\hline Risk & Risk perception $^{\mathrm{b}}$ & $3.620(0.943)$ & 1 & 5 & $2.711(1.233)$ & 1 & 5 & $-7.704 * * *$ \\
\hline Exp & $\begin{array}{l}\text { Farmers' agricultural insurance purchase experience } \\
\quad(\text { Yes }=1, \text { No }=0)\end{array}$ & $0.851(0.356)$ & 0 & 1 & $0.519(0.502)$ & 0 & 1 & $-7.166^{* * *}$ \\
\hline Pre & Risk preference score $(0-12)$ & $6.909(4.132)$ & 1 & 12 & $4.667(5.167)$ & 0 & 12 & $-4.438 * * *$ \\
\hline
\end{tabular}

WII Weather index insurance

${ }^{\text {a }}$ The values in parentheses are standard deviations

${ }^{\mathrm{b}}$ Farmers' prediction of the degree of future agricultural production risks (very low $=1$; not too high $=2$; normal $=3$; high $=4$; very high $=5$ ) $* * * p<0.01, * * p<0.05, * p<0.1$

characteristics of households that chose different risk management strategies (see Table 8). There are significant differences in variables of age, non-agricultural labor ratio, land holding, farmers' experience of natural hazards and disasters, agricultural insurance purchase experience, risk perception, and risk preference between the two groups of farmers. The average age of the farmers choosing WII was 2.5 years younger than that of the other group. This is consistent with the study by Castellani and Viganò (2017), who found that older farmers and those with a limited understanding of insurance tend to be less willing to pay for insurance. A potential explanation may be that they are less able to understand the value and claims mechanism of weather index insurance. The risk preference score of farmers who chose WII was 1.27 times that of the other group, which indicates that risk-seeking farmers prefer to choose WII.

Table 8 also shows that the non-agricultural labor ratio of households that chose weather index insurance is 0.102 lower than that of households that chose saving money. A higher non-agricultural labor ratio means more income sources and a stronger ability to bear agricultural risks. Thus households with a high non-agricultural labor ratio are less likely to demand WII. The average land holding of farmers who chose weather index insurance was $85.96 \mathrm{mu}$ (about $5.7 \mathrm{ha}$ ), which is 1.65 times that of the other group (51.96 mu, about $3.5 \mathrm{ha}$ ). This means that the more land a household owns, the more the farmer depends on agriculture, and will be more likely to purchase insurance.

Since weather, land holdings, and crop production are different in Heilongjiang and Jiangsu Provinces, descriptive statistics of the variables in the two provinces and $T$ test results are provided in Table 9 to further explore farmers' differences in the subregional samples.

The farmers in Jiangsu Province were better educated (7.9 years) than those in Heilongjiang Province (6.9 years). The impact of education on farmers' cognitive ability is profound and long term. Since the average years of sample farmers receiving education is only seven, the difference of one year is significant. The increase of one year's education experience may make farmers more likely to accept new things, which leads to higher acceptance of new insurance. The rate of non-agricultural labor in Jiangsu Province was $30.8 \%, 2.26$ times that in Heilongjiang Province. The farmers in Jiangsu Province do not entirely rely on agricultural income, and natural hazards and disasters may have less impact on households' total income than on households' income in Heilongjiang Province. The average land holding of sample households in Heilongjiang Province was $101.44 \mathrm{mu}$ (about $6.8 \mathrm{ha}$ ), 2.3 times that in Jiangsu Province, and the rate of disaster loss to farming income of farmers in Heilongjiang Province $(31.1 \%)$ was much higher than that in Jiangsu Province (16.4\%). In Heilongjiang Province, $81.7 \%$ of the sample households had suffered from disasters in the past five years, 2.1 times 


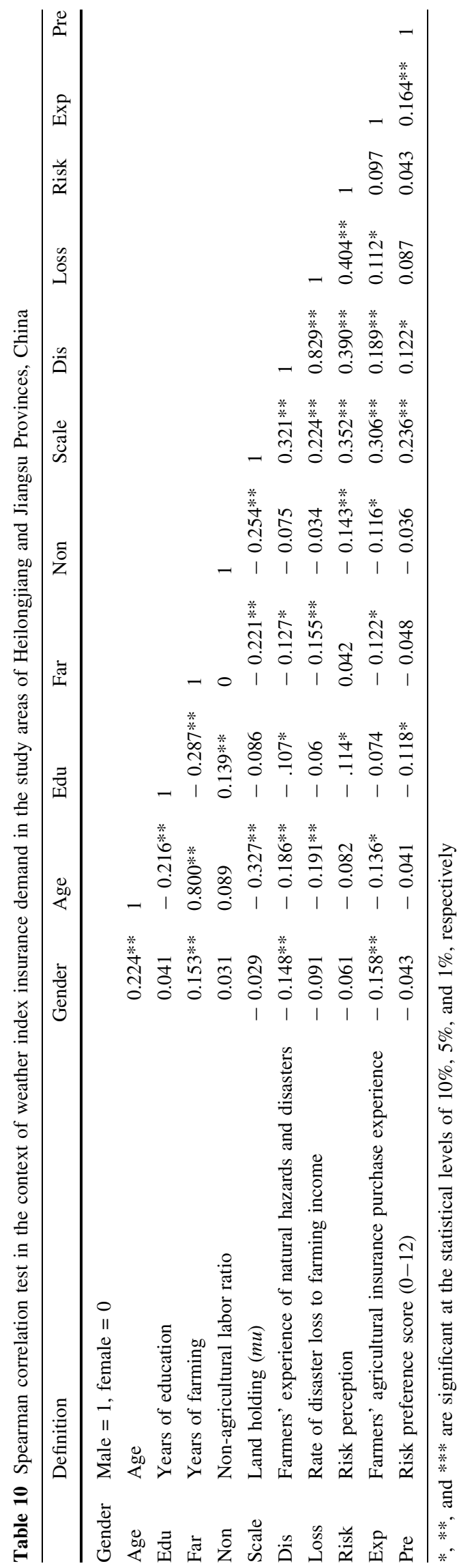

more than the sample households in Jiangsu Province. The average perception of agricultural production risk of farmers in Heilongjiang Province (3.620) was higher than that of farmers in Jiangsu Province (2.711). The probability of disaster occurrence in Jiangsu Province is lower than in Heilongjiang Province, and farmers pay less attention to natural risks in Jiangsu Province, which leads to different risk receptions of farmers in the two provinces. The average risk preference score of farmers in Heilongjiang Province was 6.909, which indicates that the farmers are risk neutral. The farmers in Jiangsu Province are risk averse (4.667). Among all the variables, except for the variable of years of farming, the differences between the variables of the farmers in the two provinces are all significant.

\subsection{Model Analysis}

The findings of farmers' demand for saving and weather index insurance highly depend on the models used. Therefore, Probit and Logistic models were both employed to further investigate the effect of farmers' characteristics on WII demand. The two regression methods allow us to make a multi-model comparison and analyze the decisionmaking behavior of farmers in more detail to make the research results more reliable. The expression of the Logistic (Eq. 1) and Probit (Eq. 2) models are as follows:

$$
\begin{aligned}
P(Y & \left.=1 \mid x_{1}, x_{2}, \ldots, x_{k}\right) \\
& =\frac{\exp \left(\alpha_{0}+\alpha_{1} x_{1}+\alpha_{2} x_{2}+\cdots+\alpha_{k} x_{k}\right)}{1+\exp \left(\alpha_{0}+\alpha_{1} x_{1}+\alpha_{2} x_{2}+\cdots+\alpha_{k} x_{k}\right)} \\
P(Y & \left.=1 \mid x_{1}, x_{2}, \ldots, x_{k}\right) \\
& =\Phi\left(\beta_{0}+\beta_{1} x_{1}+\beta_{2} x_{2}+\cdots+\beta_{k} x_{k}\right)
\end{aligned}
$$

where $P$ indicates the probability of the farmers' demand for WII; $\alpha_{0}$ and $\beta_{0}$ are constant terms; $x_{k}$ denotes the variables of the farmers' heterogeneous characteristics. $\alpha_{1}$, $\alpha_{2}, \ldots, \alpha_{k}$ and $\beta_{1}, \beta_{2}, \ldots, \beta_{k}$ are regression coefficients.

\subsubsection{Regression Analysis}

In order to prevent the influence of multiple collinearity, we removed the variables of age and loss, which have larger correlation coefficients with other variables in Table 10. The correlation coefficient between age and planting years is 0.8 , and the correlation coefficient between loss and disaster is 0.829 . The remaining variables were included in the models.

Table 11 shows the regression results of the Probit and Logistic models. In Model 1, the overall data from the three rounds of part 2 of the research experiment (see Sect. 2.4.2 on Weather Index Insurance Demand) were used, with a total of 1,032 observations, 344 in each round. To 
Table 11 Multi-model regression results in the context of weather index insurance demand in the study areas of Heilongjiang and Jiangsu Provinces, China

\begin{tabular}{|c|c|c|c|c|c|c|c|c|c|}
\hline \multirow[t]{2}{*}{ Variables } & \multirow[t]{2}{*}{ Definition } & \multicolumn{2}{|l|}{ Model 1} & \multicolumn{2}{|l|}{ Model 2} & \multicolumn{2}{|l|}{ Model 3} & \multicolumn{2}{|l|}{ Model 4} \\
\hline & & Probit & Logistic & Probit & Logistic & Probit & Logistic & Probit & Logistic \\
\hline Gender & Male $=1$, female $=0$ & $\begin{array}{l}0.0896 \\
(0.138)^{\mathrm{a}}\end{array}$ & $\begin{array}{l}0.141 \\
(0.248)\end{array}$ & $\begin{array}{l}0.0861 \\
(0.237)\end{array}$ & $\begin{array}{l}0.152 \\
(0.423)\end{array}$ & $\begin{array}{l}0.0158 \\
(0.243)\end{array}$ & $\begin{array}{l}0.00790 \\
(0.441)\end{array}$ & $\begin{array}{l}0.167 \\
(0.237)\end{array}$ & $\begin{array}{l}0.262 \\
(0.426)\end{array}$ \\
\hline Edu & Years of education & $\begin{array}{l}0.0425 * * \\
(0.0176)\end{array}$ & $\begin{array}{l}0.080 * * * \\
(0.0309)\end{array}$ & $\begin{array}{l}0.0272 \\
(0.0301)\end{array}$ & $\begin{array}{l}0.0534 \\
(0.0528)\end{array}$ & $\begin{array}{l}0.0424 \\
(0.0305)\end{array}$ & $\begin{array}{l}0.0786 \\
(0.0535)\end{array}$ & $\begin{array}{l}0.0594^{*} \\
(0.0309)\end{array}$ & $\begin{array}{l}0.111 * * \\
(0.0547)\end{array}$ \\
\hline Far & Years of farming & $\begin{array}{l}0.00597 \\
(0.0041)\end{array}$ & $\begin{array}{l}0.0110 \\
(0.0072)\end{array}$ & $\begin{array}{l}0.00545 \\
(0.0070)\end{array}$ & $\begin{array}{l}0.0102 \\
(0.0123)\end{array}$ & $\begin{array}{l}0.00712 \\
(0.0071)\end{array}$ & $\begin{array}{l}0.0127 \\
(0.0125)\end{array}$ & $\begin{array}{l}0.00553 \\
(0.0073)\end{array}$ & $\begin{array}{l}0.0104 \\
(0.0127)\end{array}$ \\
\hline Non & $\begin{array}{l}\text { Non-agricultural labor } \\
\quad \text { ratio }\end{array}$ & $\begin{array}{l}-0.507 * * * \\
(0.177)\end{array}$ & $\begin{array}{l}-0.826 * * * \\
(0.309)\end{array}$ & $\begin{array}{l}-0.676^{* *} \\
(0.303)\end{array}$ & $\begin{array}{l}-1.098 * * \\
(0.527)\end{array}$ & $\begin{array}{l}-0.520 * \\
(0.306)\end{array}$ & $\begin{array}{l}-0.835^{*} \\
(0.315)\end{array}$ & $\begin{array}{l}-0.316 \\
(0.312)\end{array}$ & $\begin{array}{l}-0.526 \\
(0.548)\end{array}$ \\
\hline Scale & Land holding $(m u)$ & $\begin{array}{l}0.000812 \\
(0.0006)\end{array}$ & $\begin{array}{l}0.00150 \\
(0.0011)\end{array}$ & $\begin{array}{l}0.000713 \\
(0.0010)\end{array}$ & $\begin{array}{l}0.00136 \\
(0.0019)\end{array}$ & $\begin{array}{l}0.000692 \\
(0.0010)\end{array}$ & $\begin{array}{l}0.00130 \\
(0.0019)\end{array}$ & $\begin{array}{l}0.00109 \\
(0.0012)\end{array}$ & $\begin{array}{l}0.00192 \\
(0.0022)\end{array}$ \\
\hline Dis & $\begin{array}{l}\text { Farmers' experience of } \\
\text { natural hazards and } \\
\text { disasters }\end{array}$ & 0.286 & 0.513 & 0.206 & 0.382 & 0.211 & 0.381 & $0.233 * *$ & $0.423^{* *}$ \\
\hline & & $(0.191)$ & $(0.335)$ & $(0.188)$ & $(0.326)$ & $(0.189)$ & $(0.328)$ & $(0.109)$ & $(0.190)$ \\
\hline Risk & Risk perception & $\begin{array}{l}0.176 * * * \\
(0.0454)\end{array}$ & $\begin{array}{l}0.301 * * * \\
(0.0799)\end{array}$ & $\begin{array}{l}0.154 * * \\
(0.0782)\end{array}$ & $\begin{array}{l}0.261 * \\
(0.137)\end{array}$ & $\begin{array}{l}0.198 * * \\
(0.0788)\end{array}$ & $\begin{array}{l}0.340 * * \\
(0.138)\end{array}$ & $\begin{array}{l}0.176 * * \\
(0.0794)\end{array}$ & $\begin{array}{l}0.304 * * \\
(0.141)\end{array}$ \\
\hline Exp & $\begin{array}{l}\text { Farmers' agricultural } \\
\text { insurance purchase } \\
\text { experience }\end{array}$ & $0.549 * * *$ & $0.927 * * *$ & $0.526 * * *$ & $0.892 * * *$ & $0.632 * * *$ & $1.070 * * *$ & $0.490 * * *$ & $0.819 * * *$ \\
\hline & & $(0.102)$ & $(0.177)$ & $(0.177)$ & $(0.303)$ & $(0.177)$ & $(0.304)$ & $(0.180)$ & $(0.314)$ \\
\hline Pre & $\begin{array}{l}\text { Risk preference score } \\
\quad(0-12)\end{array}$ & 0.0237 & 0.0389 & 0.0250 & 0.0403 & 0.0222 & 0.0355 & 0.0245 & 0.0415 \\
\hline & & $(0.0172)$ & $(0.0279)$ & $(0.0175)$ & $(0.0305)$ & $(0.0176)$ & $(0.0308)$ & $(0.0178)$ & $(0.0316)$ \\
\hline Round & $\begin{array}{l}\text { The number of rounds in } \\
\text { which farmers are in }\end{array}$ & $\begin{array}{l}0.0301 \\
(0.0576)\end{array}$ & $\begin{array}{l}0.0516 \\
(0.102)\end{array}$ & & & & & & \\
\hline Cons & & $\begin{array}{l}-0.896^{* * *} \\
(0.307)\end{array}$ & $\begin{array}{l}-1.640 * * * \\
(0.538)\end{array}$ & $\begin{array}{l}-0.592 \\
(0.481)\end{array}$ & $\begin{array}{l}-1.133 \\
(0.849)\end{array}$ & $\begin{array}{l}-0.910 * \\
(0.492)\end{array}$ & $\begin{array}{l}-1.636^{*} \\
(0.865)\end{array}$ & $\begin{array}{l}-1.032 * * \\
(0.500)\end{array}$ & $\begin{array}{l}-1.873 * * \\
(0.879)\end{array}$ \\
\hline Obs & & 1032 & 1032 & 344 & 344 & 344 & 344 & 344 & 344 \\
\hline Pseudo $\mathrm{R}^{2}$ & & 0.1084 & 0.1067 & 0.1031 & 0.1011 & 0.1217 & 0.1197 & 0.1067 & 0.1052 \\
\hline$P$-value & & 0.000 & 0.000 & 0.000 & 0.000 & 0.000 & 0.000 & 0.000 & 0.000 \\
\hline
\end{tabular}

$*, * *$, and $* * *$ are significant at the statistical levels of $10 \%, 5 \%$, and $1 \%$, respectively

${ }^{\mathrm{a}}$ The values in parentheses are standard errors

further analyze farmers' decision-making behavior during the game implementation, the data from the three individual rounds were used for regression in Models 2-4, respectively, with 344 observations for each round. Both Probit and Logistic models were employed, and there is no difference in the direction and significance levels of the coefficients in the two regression models, which means that the research results are robust. The values or absolute values of the coefficients in the Logistic model are all larger than those of the Probit model.

The variables education, non-agricultural labor ratio, farmers' agricultural insurance purchase experience, and risk perception have significant influence on farmers' demand for WII. The coefficients for education are positive and significant in Model 1 (with the overall data) and Model 4 (with the third-round data), which means that farmers who have a higher education level are more likely to choose WII. However, in the first round and the second round, the variable education is not significant. It is possible that, in the game testing weather index insurance demand (see Sect. 2.4.2), in the first two rounds, farmers may not have a full understanding of the rules of the game, and choosing weather index insurance or saving is still based on insurance experience and risk perception. Therefore these factors are significant, but education is not. But in the later stages of the game, higher education level 
Table 12 Probit and Logistic regression estimations in the context of weather index insurance demand in the study areas of Heilongjiang and Jiangsu Provinces, China

\begin{tabular}{|c|c|c|c|c|c|}
\hline \multirow[t]{2}{*}{ Variables } & \multirow[t]{2}{*}{ Definition } & \multicolumn{2}{|c|}{ Heilongjiang Province } & \multicolumn{2}{|c|}{ Jiangsu Province } \\
\hline & & Probit & Logistic & Probit & Logistic \\
\hline Gender & Male $=1$, female $=0$ & $\begin{array}{l}0.170 \\
(0.175)^{\mathrm{a}}\end{array}$ & $\begin{array}{l}0.353 \\
(0.323)\end{array}$ & $\begin{array}{l}-0.0562 \\
(0.290)\end{array}$ & $\begin{array}{l}-0.0861 \\
(0.475)\end{array}$ \\
\hline Edu & Years of education & $\begin{array}{l}0.0102 \\
(0.006)\end{array}$ & $\begin{array}{l}0.0173 \\
(0.012)\end{array}$ & $\begin{array}{l}0.00103 \\
(0.006)\end{array}$ & $\begin{array}{l}0.00323 \\
(0.010)\end{array}$ \\
\hline Far & Years of farming & $\begin{array}{l}0.0512 \\
(0.245)\end{array}$ & $\begin{array}{l}0.0967 \\
(0.461)\end{array}$ & $\begin{array}{l}0.0460 \\
(0.229)\end{array}$ & $\begin{array}{l}0.0818 \\
(0.387)\end{array}$ \\
\hline Non & Non-agricultural labor ratio & $\begin{array}{l}-1.236 * * * \\
(0.292)\end{array}$ & $\begin{array}{l}-2.204 * * * \\
(0.526)\end{array}$ & $\begin{array}{l}-0.705^{*} \\
(0.407)\end{array}$ & $\begin{array}{l}-1.255^{*} \\
(0.677)\end{array}$ \\
\hline Scale & Land holding $(m u)$ & $\begin{array}{l}-0.0009 \\
(0.0007)\end{array}$ & $\begin{array}{l}0.0002 \\
(0.0015)\end{array}$ & $\begin{array}{l}0.001 \\
(0.0009)\end{array}$ & $\begin{array}{l}0.002 \\
(0.0016)\end{array}$ \\
\hline Dis & Farmers' experience of natural hazards and disasters & $\begin{array}{l}0.055^{* * * *} \\
(0.0173)\end{array}$ & $\begin{array}{l}0.091 * * * \\
(0.0319)\end{array}$ & $\begin{array}{l}0.272 \\
(0.250)\end{array}$ & $\begin{array}{l}0.472 \\
(0.417)\end{array}$ \\
\hline Risk & Risk perception & $\begin{array}{l}0.0506 \\
(0.0742)\end{array}$ & $\begin{array}{l}0.0615 \\
(0.137)\end{array}$ & $\begin{array}{l}0.155 * * \\
(0.0671)\end{array}$ & $\begin{array}{l}0.249 * * \\
(0.111)\end{array}$ \\
\hline Exp & Farmers' agricultural insurance purchase experience & $\begin{array}{l}0.793 * * * \\
(0.170)\end{array}$ & $\begin{array}{l}1.413 * * * \\
(0.303)\end{array}$ & $\begin{array}{l}0.251 * \\
(0.139)\end{array}$ & $\begin{array}{l}0.399 * \\
(0.231)\end{array}$ \\
\hline Pre & Risk preference score $(0-12)$ & $\begin{array}{l}-0.416^{*} \\
(0.236)\end{array}$ & $\begin{array}{l}-0.859 * \\
(0.479)\end{array}$ & $\begin{array}{l}0.0029 \\
(0.0136)\end{array}$ & $\begin{array}{l}0.0052 \\
(0.0227)\end{array}$ \\
\hline Constant & & $\begin{array}{l}-0.167 \\
(0.495)\end{array}$ & $\begin{array}{l}-0.195 \\
(0.893)\end{array}$ & $\begin{array}{l}0.452 * * * \\
(0.169)\end{array}$ & $\begin{array}{l}0.763 * * * \\
(0.290)\end{array}$ \\
\hline Observations & & 627 & 627 & 405 & 405 \\
\hline Pseudo $\mathrm{R}^{2}$ & & 0.1400 & 0.1371 & 0.0835 & 0.0829 \\
\hline$P$-value & & 0.000 & 0.000 & 0.000 & 0.000 \\
\hline
\end{tabular}

$*, * *$, and $* * *$ are significant at the statistical levels of $10 \%, 5 \%$, and $1 \%$, respectively

${ }^{\mathrm{a}}$ The values in parentheses are standard errors

can help farmers to better understand the rules of the game and how to make more profits and make more rational decisions. Therefore, the variable education has become significant in the third round (Model 4). As the four-part research experiment proceeds, the subjects' understanding of insurance could be improved and it plays a critical role in their purchase decision, which could further influence their participation in purchasing weather index insurance (Ye et al. 2016). Better education enables faster assimilation of the information provided in the insurance contract and that accurate understanding of the insurance allows farmers to link the crop insurance to their needs for risk transfer (Wang et al. 2016). Therefore, in the regression result with the third-round data the variable education is significant.

The coefficients for non-agricultural labor ratio are negative and significant in Model 1 and Model 2. This means that with more laborers engaged in non-farming activities, households would rely less on agriculture and their demand for agricultural insurance would be lower. Off-farm activities increase households' income sources and improve their ability of risk diversification (Castellani and Viganò 2017), so farmers do not need to purchase agricultural insurance to deal with risks. The coefficients for agricultural insurance purchase experience are all positive and significant in Models 1-4. The result is consistent with the study by Wang et al. (2012), who found that experience of insurance showed a strong correlation with the regional overall acceptance of disaster insurance. Farmers' risk perception has a significant and positive impact on farmers' WII demand in Models 1-4. This is consistent with the study by Jensen et al. (2016), who suggested that demand for WII seems to increase in response to the potential for future natural shocks, which dramatically influences farmers' willingness to pay.

To further explore the impact of farmers' differences with respect to demand for WII in the two provinces, the 
Table 13 Robustness test of the results of the weather index insurance demand test in the study areas of Heilongjiang and Jiangsu Provinces, China

\begin{tabular}{|c|c|c|c|c|c|}
\hline Variables & Definition & Coefficient & Standard errors & $\mathrm{z}$ & Probability \\
\hline $\begin{array}{l}\text { Gender } \\
0.275\end{array}$ & Male $=1$, female $=0$ & 0.279 & 0.257 & & $-1.0 \times$ \\
\hline $\begin{array}{l}\text { Edu } \\
0.599\end{array}$ & Years of education & 0.0192 & 0.0365 & & -0.526 \\
\hline Far & Years of farming & -0.008 & 0.0084 & 0.95 & 0.342 \\
\hline $\begin{array}{l}\text { Non } \\
0.082\end{array}$ & Non-agricultural labor ratio & $-0.5576^{*}$ & 0.3208 & & -1.74 \\
\hline Scale & Land holding $(m u)$ & 0.0005 & 0.0007 & 0.70 & 0.486 \\
\hline Dis & Farmers' experience of natural hazards and disasters & 0.2553 & 0.1766 & 1.45 & 0.148 \\
\hline Exp & Farmers' agricultural insurance purchase experience & $0.5724 * * *$ & 0.1805 & 3.17 & 0.002 \\
\hline Risk & Risk perception & $0.1661 * *$ & 0.0744 & 1.97 & 0.029 \\
\hline Pre & Risk preference score $(0-12)$ & 0.0227 & 0.0173 & 1.31 & 0.191 \\
\hline Wald $\operatorname{chi} 2(7)=41.10^{* * *}$ & Pseudo $\mathrm{R}^{2}=0.12244 \mathrm{c}$ & & & & \\
\hline
\end{tabular}

$*, * *$, and $* * *$ are significant at the levels of $10 \%, 5 \%$, and $1 \%$, respectively

regression results of the samples by province are provided in Table 12.

In Table 12, the variables non-agricultural income and insurance purchase experience have the same effect on the farmers' demand for index insurance in the two provinces, and have the same direction as the total samples, while the impact of the variables disaster experience, risk perception, and risk preference are different in the two provinces. The variable disaster experience is only significant in Heilongjiang Province, and its coefficient is 0.0551 . The data in Table 9 show that the sample farmers in Heilongjiang Province have suffered more disasters and losses in recent years, which made them more willing to take up WII to resist the risks. The variable risk perception is only significant in Jiangsu Province. The coefficient is 0.155 , which means that farmers in Jiangsu are more willing to buy WII when they perceive that future risks are greater. Linking the risk preference score of farmers in Jiangsu Province to their risk perception shows that the average risk perception and the risk preference score are all lower than those of farmers in Heilongjiang Province. This means that farmers in Jiangsu Province are more risk averseeven if they predict that the risk of agricultural production in the future will be low, they will take up formal risk management methods to resist risks.

\subsubsection{Robustness Test}

To test if the results are robust, the times that farmers chose WII in the three rounds of part 2 of the research experiment (see Sect. 2.4.2 on Weather Index Insurance Demand) was used as the proxy variable to measure the farmers' demand for WII. The robustness test results are shown in Table 13. The effect of the variables non-agricultural labor ratio, agricultural insurance purchase experience, and risk perception are significant, consistent with the results in Table 11. This means that the research results are robust.

\section{Discussion}

This study explored farmers' demand for WII and informal risk management strategies by constructing Pobit and Logistic regression models. There are similarities and differences between the results of this study and other similar studies.

Farmers' demand for crop insurance differs according to their risk management tools, as well as the implementation of self-insurance mechanisms and diversification (Sakurai and Reardon 1997; Skees 2008; Akter et al. 2009). Different studies have obtained different results regarding this relationship. Dercon and Gollin (2014) and Mobarak and 
Rosenzweig (2012) argued that due to the inherent shortcomings of WII, informal risk management and WII are complementary-the former mitigates idiosyncratic risk while the latter is more effective against covariate risk. Hess and Hazell (2009), Skees (2008), and the World Bank (2011) found that sound self-insurance strategies and other informal risk management instruments have a crowdingout effect on the utility of new insurance products. But Madhur et al. (1994) and Norton et al. (2014) suggested that smallholder farmers prefer WII over other risk management alternatives. If the risk management methods of farmers are not adequate, their demand for WII is high. In this study, we found that compared with diversifying risks through saving, farmers prefer to adopt WII, which is in line with findings by Dercon and Gollin (2014) and Mobarak and Rosenzweig (2012).

In addition to informal risk management tools, there are some other factors that influence agricultural insurance demand. Higher total income may indicate higher affordability, and may increase the likelihood of agricultural insurance participation. Liu et al. (2016) suggested that household net income boosts agricultural insurance consumption. But Wang et al. (2016) and Ye et al. (2016) noted that the effect of total income on agricultural insurance demand is not significant. However, Jin et al. (2016) indicated that farmers' household income is negatively and significantly associated with the insurance participation practice. In this study, the non-agricultural labor ratio serves as an indicator of off-farm income, and has a significant negative impact on the demand for weather index insurance. This is consistent with the study by Jin et al. (2016), who argued that, instead of buying insurance, richer farmers could recover through other means such as off-farm activities, if their farms are damaged by bad weather conditions. The finding is close to that by Ye et al. (2016). It indicates that on-farm income proportion is positively linked to crop insurance participation.

Insurance participation experience, particularly indemnity experience, and experiences in commercial insurance can substantially increase the probability of participation in agricultural insurance (Wang et al. 2012; Ye et al. 2016). Timely and appropriate cash payouts can enhance farmers' trust in insurers and they are more likely to purchase crop insurance (Wang et al. 2011; Wang et al. 2016; Cai and Song 2017). In this study, farmers' agricultural insurance purchase experience had a significant positive impact on the demand for weather index insurance, which is consistent with previous studies.

Risk perception is often regarded as an important driver affecting disaster preparedness in farming households (Liu et al. 2016; Xu et al. 2018). But the results of different studies are not consistent. Yang et al. (2019) and Liu et al. (2019) indicated that individual risk perception has a positive effect on the willingness to pay for agricultural insurance. Ye and Wang (2013) and Wang et al. (2012) found that the perceived risk does not directly affect disaster insurance participation. In this study, farmers' risk perception had a positive effect on the demand for agricultural insurance.

Education is related to household disaster preparedness behavior ( $\mathrm{Xu}$ et al. 2018). Education helps farmers to understand the content of the insurance contract and to link the policies to their own risk-transfer needs. Better educated farmers are more likely to purchase crop insurance, probably because they can better understand the contract (Wang et al. 2016; Ye et al. 2016). In this study, there is a significant positive correlation between the farmers' education level and their demand for agricultural index insurance.

\section{Conclusion}

To examine farmers' demand for weather index insurance and informal risk management strategies, and the main drivers that influence the demand, field experiments were conducted to collect data on farmers' demand in a dynamic context in Heilongjiang Province (Northeast China) and Jiangsu Province (East China). Logistic model, Probit model, and independent sample $T$-test were used to investigate the influence of informal risk management and farmers' characteristics on WII demand. The results show that the farmers prefer weather index insurance to informal risk management strategies. In the three test rounds, the weather conditions changed randomly, which would affect household income, but the participation rate of WII was always higher than $80 \%$. This means that the farmers believed that WII is more effective than informal risk management strategies.

Understanding the main drivers that influence farmers' insurance demand is critical to product design. The research results show that the variables non-agricultural labor ratio, farmers' risk perception, education, and agricultural insurance purchase experience are all main drivers that significantly affect farmers' demand for WII. The regression by province results show that the farmers' WII demand and the influencing factors in the two provinces are different. The results have some policy implications. The findings show that the farmers' agricultural insurance purchase experience affects WII demand. The government should conduct some pilot programs in the main agricultural production areas with high natural risks in each province to help farmers understand the WII compensation mechanism and comprehend the important role of WII in dealing with extreme weather risk and smoothing income fluctuations. Insurance companies should subdivide the 
insurance market according to the heterogeneity of farmers' characteristics and provide products with different coverage levels and premiums to meet their diversified needs. Due to regional differences in insurance demand, differentiated strategies should also be adopted when insurance companies promote products in different regions.

This study was subject to some limitations. First, the research was conducted in Northeast China and East China, where agro-climatic, geographic, and farmers' individual characteristics are different from other parts of China. Whether the results can be generalized beyond the study areas is questionable. Second, farmers' experience of commercial insurance purchase, cost of insurance product, government disaster relief, and other factors may also affect their decision making, but these other factors were not included in our model. Furthermore, unobserved characteristics and external environment variables that may cause the difference between the two provinces were not included in the model, limited by the experimental design. Finally, informal risk management methods include household savings, borrowing from friends and relatives, mutual support networks of neighbors, diversified cultivation, and non-farming income, but only saving was included in the experiment design. A more complete experiment with more diverse samples and more influencing drivers is needed to gain a fuller understanding of demand for WII and informal risk management methods.

Acknowledgements This research was funded by the National Natural Science Foundation of China project "The Weather Index Insurance Demand and Its Influence on Farmers' Behavior Research" (Grant No. 71573129), and by the Nanjing Agricultural University Central Universities Fundamental Research Funds for Humanities and Social Sciences (Grant Nos. SKCX2015011 and SKJD2014001).

Open Access This article is licensed under a Creative Commons Attribution 4.0 International License, which permits use, sharing, adaptation, distribution and reproduction in any medium or format, as long as you give appropriate credit to the original author(s) and the source, provide a link to the Creative Commons licence, and indicate if changes were made. The images or other third party material in this article are included in the article's Creative Commons licence, unless indicated otherwise in a credit line to the material. If material is not included in the article's Creative Commons licence and your intended use is not permitted by statutory regulation or exceeds the permitted use, you will need to obtain permission directly from the copyright holder. To view a copy of this licence, visit http://creativecommons. org/licenses/by/4.0/.

\section{References}

Akter, S., R. Brouwer, S. Choudhury, and S. Aziz. 2009. Is there a commercially viable market for crop insurance in rural Bangladesh. Mitigation and Adaptation Strategies for Global Change 14(3): 215-229.
Barnett, B.J., C.B. Barrett, and J.R. Skees. 2008. Poverty traps and index-based risk transfer products. World Development 36(10): $1766-1785$.

Berhane, G., D. Clarke, S. Dercon, R.V. Hill, and A.S. Taffesse. 2013. Insuring against the weather. ESS Research Note No. 20. Washington, DC: IFPRI.

Binswanger, H.P. 1980. Attitudes toward risk: Experimental measurement in rural India. American Journal of Agricultural Economics 62(3): 395-407.

Binswanger-Mkhize, H., N. Mukherjee, and K. Parikh. 2012. India 2039-Transforming agriculture: Productivity, markets, and institutions. Global Journal of Emerging Market Economies 4(2): 197-226.

Bogale, A. 2015. Weather-indexed insurance: An elusive or achievable adaptation strategy to climate variability and change for smallholder farmers in Ethiopia. Climate and Development 7(3): 246-256.

Brick, K., and M. Visser. 2015. Risk preferences, technology adoption and insurance uptake: A framed experiment. Journal of Economic Behavior \& Organization 118(C): 383-396.

Brouwer, R., B.D. Tinh, and T.H. Tuan. 2013. Modeling demand for catastrophic flood risk insurance in coastal zones in Vietnam using choice experiments. Environment and Development Economics 19(2): 228-249.

Cai, J., and C. Song. 2017. Do disaster experience and knowledge affect insurance take-up decisions? Journal of Development Economics 124(C): 83-94.

Castellani, D., and L. Viganò. 2017. Does willingness-to-pay for weather index-based insurance follow covariant shocks. International Journal of Bank Marketing 35(3): 516-539.

Castellani, D., B. Tamre, and L. Viganò. 2014. A discrete choice analysis of smallholder farmers' preferences and willingness to pay for weather derivatives: Evidence from Ethiopia. Journal of Applied Business Research 30(6): 1671-1692.

Clarke, D., F. Nicola, R.V. Hill, N. Kumar, and P.A. Mehta. 2015. Chat about insurance: Experimental results from rural Bangladesh. Applied Economic Perspectives and Policy 37(3): 477-501.

Clarke, D.J. 2011. A theory of rational demand for index insurance. Economics Series Working Papers 572. Department of Economics, University of Oxford, Oxford, UK.

Clarke, D.J., and S. Dercon. 2016. Dull disasters? How planning ahead will make a difference. Oxford, UK: Oxford University Press.

Clarke, D.J., and S. Dercon. 2009. Insurance, credit and safety nets for the poor in a world of risk. Working Papers 81. Department of Economics and Social Affairs, United Nations, New York.

Clement, K.Y., W.J. Wouter Botzen, R. Brouwer, and J.C.J.H. Aerts. 2018. A global review of the impact of basis risk on the functioning of and demand for index insurance. International Journal of Disaster Risk Reduction 28: 845-853.

Cole, S., X. Giné, J. Tobacman, P. Topalova, R. Townsend, and J. Vickery. 2013. Barriers to household risk management: Evidence from India. American Economic Journal: Applied Economics 5(1): 104-135.

Cole, S., D. Stein, and J. Tobacman. 2014. Dynamics of demand for index insurance: Evidence from a long-run field experiment. The American Economic Review: Papers and Proceedings 104(5): 284-290.

Collier, B., J. Skees, and B. Barnett. 2009. Weather index insurance and climate change: Opportunities and challenges in lower income countries. The Geneva Papers on Risk and Insurance Issues and Practice 34(3): 401-424.

Colson, G., O.A. Ramirez, and S.F. Fu. 2014. Crop insurance savings accounts: A viable alternative to crop insurance?. Applied Economic Perspectives and Policy 36(3): 527-545. 
Dercon, S., and D. Gollin. 2014. Agriculture in African development: Theories and strategies. Annual Review of Resource Economics 6(1): 471-492.

Dercon, S., R.V. Hill, D. Clarke, I. Outes-Leon, and A. Seyoum Tasesse. 2014. Offering rainfall insurance to informal insurance groups: Evidence from a field experiment in Ethiopia. Journal of Development Economics 106(C): 132-143.

Fahad, S., J. Wang, G. Hu, H. Wang, X. Yang, A. Shah, N.T.L. Huong, and A. Bilal. 2018. Empirical analysis of factors influencing farmers crop insurance decisions in Pakistan: Evidence from Khyber Pakhtunkhwa Province. Land Use Policy 75: 459-467.

Farrin, K., and M.J. Miranda. 2015. A heterogeneous agent model of credit-linked index insurance and farm technology adoption. Journal of Development Economics 116(C): 199-211.

Feng, W.L., and M. Yang. 2011. Weather index insurance: China's agricultural catastrophe risk management tool innovation. Journal of Finance and Economics 6: 92-95 (in Chinese).

Giné, X., and D. Yang. 2009. Insurance, credit, and technology adoption: Field experimental evidence from Malawi. Journal of Development Economics 89(1): 1-11.

Giné, X., R. Townsend, and J. Vickery. 2008. Patterns of rainfall insurance participation in rural India. The World Bank Economic Review 22(3): 539-566.

Han, Z., H. Wang, Q. Du, and Y. Zeng. 2017. Natural hazards preparedness in Taiwan: A comparison between households with and without disabled members. Health Security 15(6): 575-581.

Hazell, P.B.R., and U. Hess. 2010. Drought insurance for agricultural development and food security in dryland areas. Food Security 2(4): 395-405.

Hellmuth, M.E., D.E. Osgood, U. Hess, A. Moorhead, and H. Bhojwani (eds.). 2009. Index insurance and climate risk: Prospects for development and disaster management. Climate and Society No. 2, International Research Institute for Climate and Society (IRI), Columbia University, New York, USA.

Hess, U., and P.B.R. Hazell. 2009. Innovations in insuring the poor: Sustainability and scalability of index-based insurance for agriculture and rural livelihoods. Washington, DC: International Food Policy Research Institute.

Hill, R.V., J. Hoddinott, and N. Kumar. 2013. Adoption of weatherindex insurance: Learning from willingness to pay among a panel of households in rural Ethiopia. Agricultural Economics 44(4-5): 385-398.

Hisali, E., P. Birungi, and F. Buyinza. 2011. Adaptation to climate in Uganda: Evidence from micro level data. Global Environmental Change 21(4): 1245-1261.

Hoogeveen, J., E. Tesliuc, R. Vakis, and S. Dercon. 2004. A guide to the analysis of risk vulnerability and vulnerable groups. Washington, DC: World Bank (Social Protection Unit, Human Development Network).

Jensen, N.D., C.B. Barrett, and A.G. Mude. 2016. Index insurance quality and basis risk: Evidence from northern Kenya. American Journal of Agricultural Economics 98(4-5): 1450-1469.

Jin, J., W.Y. Wang, and X.M. Wang. 2016. Farmers' risk preferences and agricultural weather index insurance uptake in rural China. International Journal of Disaster Risk Science 7(3): 366-373.

Karlan, D., R. Osei, I. Osei-Akoto, and C. Udry. 2014. Agricultural decisions after relaxing credit and risk constraints. The Quarterly Journal of Economics 129(2): 597-652.

Kong, R., and Y.L. Yuan. 2010. An empirical study on the influencing factors of farmers' weather insurance purchase intention in Western China-Based on the survey of farmers in the ShanxiGansu Region. Finance and Trade Economics 910: 45-50 (in Chinese).

Linnerooth, J., R. Mechler, and G. Pflug. 2005. Refocusing disaster aid. Science 309(5737): 1044-1046.
Liu, F., C.P. Corcoran, J. Tao, and J. Cheng. 2016. Risk perception, insurance recognition and agricultural insurance behaviour-An empirical based on dynamic panel data in 31 provinces of China. International Journal of Disaster Risk Reduction 20: 19-25.

Liu, X.L., Y.M. Tang, J.H. Ge, and M.J. Miranda. 2019. Does experience with natural disasters affect willingness-to-pay for weather index insurance? Evidence from China. International Journal of Disaster Risk Reduction 33: 33-43.

Lu, Z.J., Q. Song, K.B. Liu, W.B. Wu, Y.X. Liu, R. Xin, and D.M. Zhang. 2017. Rice cultivation changes and its relationships with geographical factors in Heilongjiang Province, China. Journal of Integrative Agriculture 16(10): 2274-2282.

Madhur, G., P. Hazell, and H. Alderman. 1994. Rural households demand for drought insurance. World Bank policy research working paper No. 1383. Washington, DC: World Bank.

Marr, A., A. Winkel, M. Van Asseldonk, R. Lensink, and E. Bulteet. 2016. Adoption and impact of index-insurance and credit for smallholder farmers in developing countries: A systematic review. Agricultural Finance Review 76: 94-118.

Miranda, M.J., and K. Farrin. 2012. Index insurance for developing countries. Applied Economic Perspectives and Policy 34(3): 391-427.

Miranda, M.J., and D.V. Vedenov. 2001. Innovations in agricultural and natural disaster insurance. American Journal of Agricultural Economics 83(3): 650-655.

Mobarak, A.M., and M.R. Rosenzweig. 2012. Selling formal insurance to the informally insured. Working Papers 1007, Economic Growth Center, Yale University. https://doi.org/10.2139/ssrn. 2009528.

Mosley, P. 2001. Insurance against poverty? The new generation of agricultural microinsurance schemes. Small Enterprise Development 12(1): 51-58.

Mozumder, P., A.K. Bohara, and R.P. Berrens. 2009. Private transfers to cope with a natural disaster: Evidence from Bangladesh. Environment and Development Economics 14(2): Article 187.

National Bureau of Statistics. 2020. China statistical yearbook 2020. Beijing: China Statistics Press.

Nie, R., and D. Shen. 2016. An empirical study on the impact of agricultural insurance participation decision-making on farmers' consumption behavior. Journal of Northeast University (Social Science) 18: 362-368 (in Chinese).

Norton, M., D. Osgood, M. Madajewicz, E. Holthaus, N. Peterson, R. Diro, C. Mullally, T.-L. Teh, and M. Gebremichael. 2014. Evidence of demand for index insurance: Experimental games and commercial transactions in Ethiopia. Journal of Development Studies 50(5): 630-648.

Patt, A., N. Peterson, M. Carter, M. Velez, U. Hess, and P. Suarez. 2009. Making index insurance attractive to farmers. Mitigation and Adaptation Strategies for Global Change 14(8): 737-753.

Sakurai, T., and T. Reardon. 1997. Potential demand for drought insurance in Burkina Faso and its determinants. American Journal of Agricultural Economics 79(4): 1193-1207.

Sarris, A. 2013. Weather index insurance for agricultural development: Introduction and overview. Agricultural Economics 44(4-5): 381-384.

Sawada, Y. 2007. The impact of natural and manmade disasters on household welfare. Agricultural Economics 37(S1): 59-73.

Skees, J.R. 2003. Risk management challenges in rural financial markets: Blending risk management innovations with rural finance. Paper presented at Paving the Way Forward for Rural Finance-An International Conference on Best Practices, 2-4 June 2003, Washington, DC, USA.

Skees, J.R. 2008. Challenges for use of index-based weather insurance in lower income countries. Agricultural Finance Review 68: 197-217. 
Skees, J.R., and B.J. Barnett. 2006. Enhancing microfinance using index based risk transfer products. Agricultural Finance Review 66(2): 235-250.

Skees, J.R., P. Varangis, D. Larson, and P. Siegel. 2002. Can financial markets be tapped to help poor people cope with weather risks? Policy Research Working Paper No. 2812. Washington, DC: World Bank.

Tong, Q., B. Swallow, L. Zhang, and J. Zhang. 2019. The roles of risk aversion and climate-smart agriculture in climate risk management: Evidence from rice production in the Jianghan Plain, China. Climate Risk Management 26: 1-13.

Trærup, S.L. 2012. Informal networks and resilience to climate change impacts: A collective approach to index insurance. Global Environmental Change 22(1): 255-267.

Turvey, C.G., and R. Kong. 2010. Weather risk and the viability of weather insurance in China's Gansu, Shanxi, and Henan provinces. China Agricultural Economic Review 2(1): 5-24.

Wang, M., C. Liao, S.N. Yang, W.T. Zhao, M. Liu, and P.J. Shi. 2012. Are people willing to buy natural disaster insurance in China? Risk awareness, insurance acceptance, and willingness to pay. Risk Analysis 32(10): 1717-1740.

Wang, M., P.J. Shi, T. Ye, M. Liu, and M.Q. Zhou. 2011. Agriculture insurance in China: History, experience, and lessons learned. International Journal of Disaster Risk Science 2(2): 10-22.

Wang, M., T. Ye, and P. Shi. 2016. Factors affecting farmers' crop insurance participation in China. Canadian Journal of Agricultural Economics 64(3): 479-492.

World Bank. 2011. Weather index insurance for agriculture: Guidance for development practitioners. Agriculture and Rural Development Discussion Paper No. 50. Washington, DC: World Bank.

Xiao, Y.G., and J. Yao. 2019. Double trigger agricultural insurance products with weather index and yield index. China Agricultural Economic Review 37(9): 299-316.
Xu, D., L. Peng, S.Q. Liu, and X. Wang. 2018. Influences of risk perception and sense of place on landslide disaster preparedness in Southwestern China. International Journal of Disaster Risk Science 9(2): 167-180.

Yang, F., J. Tan, and L. Peng. 2019. The effect of risk perception on the willingness to purchase hazard insurance-A case study in the Three Gorges Reservoir region, China. International Journal of Disaster Risk Reduction 45: Article 101379.

Ye, T., and M. Wang. 2013. Exploring risk attitude by a comparative experimental approach and its implication to disaster practice in China. Journal of Risk Research 16(7): 861-878.

Ye, T., Y.B. Liu, J.W. Wang, M. Wang, and P.J. Shi. 2016. Farmers' crop insurance perception and participation decisions: Empirical evidence from Hunan, China. Journal of Risk Research 20(5): $1-14$.

Ye, T., M. Wang, W.Y. Hu, Y.B. Liu, and P.J. Shi. 2017. High liabilities or heavy subsidies: Farmers' preferences for crop insurance attributes in Hunan, China. China Agricultural Economic Review 9(4): 588-606.

Ye, T., W.Y. Hu, B.J. Barnett, J.W. Wang, and Y. Gao. 2020. Area yield index insurance or farm yield crop insurance? Chinese perspectives on farmers' welfare and government subsidy effectiveness. Journal of Agricultural Economics 71(1): 144-164.

Zhao, Y.F., Z.H. Chai, M.S. Delgado, and P.V. Preckel. 2016. An empirical analysis of the effect of crop insurance on farmers' income: Results from inner Mongolia in China. China Agricultural Economic Review 8(2): 299-313.

Zhang, X., W.X. Yin, J. Wang, T. Ye, J.T. Zhao, and J. Wang. 2015. Crop insurance premium ratemaking based on survey data: A case study from Dingxing County, China. International Journal of Disaster Risk Science 6(3): 207-215.

Zhou, S. 2010. Preventive savings behavior of urban residents in China. World Economics 8: 112-122 (in Chinese). 